\title{
Mental health services in Romania
}

\author{
G. Radhakrishnan, Lecturer, Department of Psychological Medicine, Ely Hospital, \\ Cardiff CF5 5XE
}

Since the demise of the Ceaucescu regime in Romania, the media has been presenting a grim catalogue of life in Ceaucescu Romania. Even as these stark images were unfolding, Bristol MENCAP, independent of the national organisation, was putting together a package of humanitarian aid directed, predominantly in the first instance, to orphanages in and around the city of Cluj-Napoca in the province of Transylvania, Romania. Our department has close links with the National Executive of MENCAP and we were approached by Bristol MENCAP to undertake a fact-finding mission on the current state of professional services for the mentally handicapped in general, and that of the Department of Psychology at Cluj-Napoca University in particular.

I was the guest of Professor H.P. of the Department of Psychology, itself a member of the Faculty of History and Philosophy at the University of ClujNapoca. I was struck by the warmth of the hospitality. It was not very long, however, before I started learning of the extent of the repression that the country had endured. I had expected to see food and petrol queues, and of course, I saw them. It is only when one witnesses first-hand the rows of concrete blocks that have replaced the original village communities that one really begins to appreciate the terrible legacy left behind by the dictator.

It came as a surprise to me to learn that departments of psychology across Romania had been banned by Ceaucescu in 1976, and that 1990 was the first year since then that any university had had a fresh intake of students in psychology. Premises and equipment once used by psychologists were given over to other more favoured departments. The department has a few small rooms given over to office space, and one lecture theatre that can at the present time accommodate all of the first batch of students; but of course, in five years' time when the current batch is in its final year, the student complement would be in excess of 500 . The department is currently negotiating for additional accommodation, but has to compete with other departments with at least equal claims. Building space is not the only problem: there is a general dearth of textbooks and journals; there is no secretarial assistance; there is only one English language typewriter in the entire faculty, so that in attempting to correspond with the outside world, individuals have to take their turn at the typewriter. There were perhaps half-a-dozen computers dating from the 1960 s, only one of which worked. Students and indeed academic staff have no means of getting to the population they would be serving apart from erratic public transport. For example, if a trainee psychologist wished to go to a special school on a regular basis, this would be virtually impossible unless the school was within walking distance of the Institution.

In addition to the department of psychology, I visited a provincial psychiatric hospital, an orphanage and a special school. From what I was able to gather on psychiatric services, it seemed that the further away one moved from the capital or other large city, the worse the prospects of psychiatric care. There seemed to be three main categories of psychiatric care. Firstly, so-called institutes, the equivalent of teaching or large district general hospitals which are relatively (and I underline relatively) well resourced with a reasonable attempt at multidisciplinary working, although it was my impression that psychiatrists did not much care to accept a point of view different from their own. Secondly, there are the more rural or provincial facilities such as the one I visited. The medical staff consisted of a medical director and three psychiatrists looking after an average of 30 patients each, of whom approximately 20 were chronic in-patients. There were no other professionals in this hospital (psychologists, occupational therapists, physiotherapists, speech therapists or any of the creative therapies). There were some carers described as 'nurses' although they did not have any formal training apart from what they picked up in the course of their employment. Patients have no daytime occupation whatsoever, and simply shuffle around or huddle in corners or just stay in bed. Little privacy is afforded to patients - perhaps six inches separates adjoining beds. There were no new books and no journals at all. The only drugs that this particular hospital had had was a consignment of two sample boxes received from Germany and Finland about two months prior to my visit, but these had long since been used up. Overall, the picture was one of hopeless, unchanging monotony.

The third category of psychiatric facility are the so-called sanataria, equivalent to the large longstay hospitals. Although I did not visit one, from the description I had of an average sanatarium, conditions would be almost sub-human. I have some evidence that people are still chained up, may be 
beaten into submission by staff, and by any standards at all, live in a state of considerable humiliation. The patient population would be a mixed bag of chronic psychotics and people who had 'graduated' from the special schools.

Children thought to be mentally handicapped are sent to special schools. The decision to send a child to a special school appears to be based on completely arbitrary criteria. If a standardised system of assessment exists, teachers in the special schools I visited were unable to tell me what this was. Special schools appeared to be tiered into two main categories depending on parents' ability to pay. Children of more privileged families attend quasi-private schools where parents contribute financially towards their child(ren)'s upkeep. I went to one such school which in the context of conditions in Cluj-Napoca generally, was reasonably well provided for.

The average State-run special school presents an awful picture of deprivation and squalor. The one I visited was a residential institution on the outskirts of Cluj-Napoca in the grounds of an old castle, housing about 300 children. There are few staff; what staff are available organise the children into morning sessions given over to basic academic training, for example, arithmetic and language; and the afternoon sessions are used for skills training. Two educational psychologists supervise the afternoon sessions for the whole school. In common with provincial psychiatric services and the sanataria, there are no facilities for leisure or recreation, with children left largely to their own devices. Large crowded dormitories provide sleeping accommodation. Classrooms double as storage areas - equipment used for teaching and the children's meagre possessions are stored in cupboards along the classroom walls. Desks provide makeshift ping-pong tables. Sanitary facilities are virtually non-existent, I was warned against going around to an open-fronted toilet block (five toilets for the entire institution). There was no toilet paper or piped water. Faeces were strewn everywhere including outside the toilets.

By the time children in these schools reach the age of 17, they have to be classified as either 'recovered' or 'irrecoverable'. Those deemed 'recovered' supposedly join the mainstream of society, where I suspect they would be employed as labourers in factories or farms; those unfortunate individuals deemed 'irrecoverable' are sent on to the so-called sanataria, there to languish until the end of their days. Again, criteria for 'recovery' appear to be quite arbitrary.

From all the establishments that I visited I got extensive lists of materials and equipment that were urgently needed in order to get on with daily living. These included all kinds of stationery, video and television equipment with teaching tapes, computer systems that could be used for teaching children, woodworking and metalworking equipment, perhaps a minibus (all this, of course, in addition to food, clothing, toys, the provision of heating and refrigeration equipment and so on, that a large number of charities from different countries carry on providing).

There are signs of recovery. Some of the orphanages that have been depicted in the media as places of utter squalor have been transformed with the massive outpouring of aid from Western nations. There is also some evidence of an entrepreneurial spirit with some university departments seeking to form links with some Western universities.

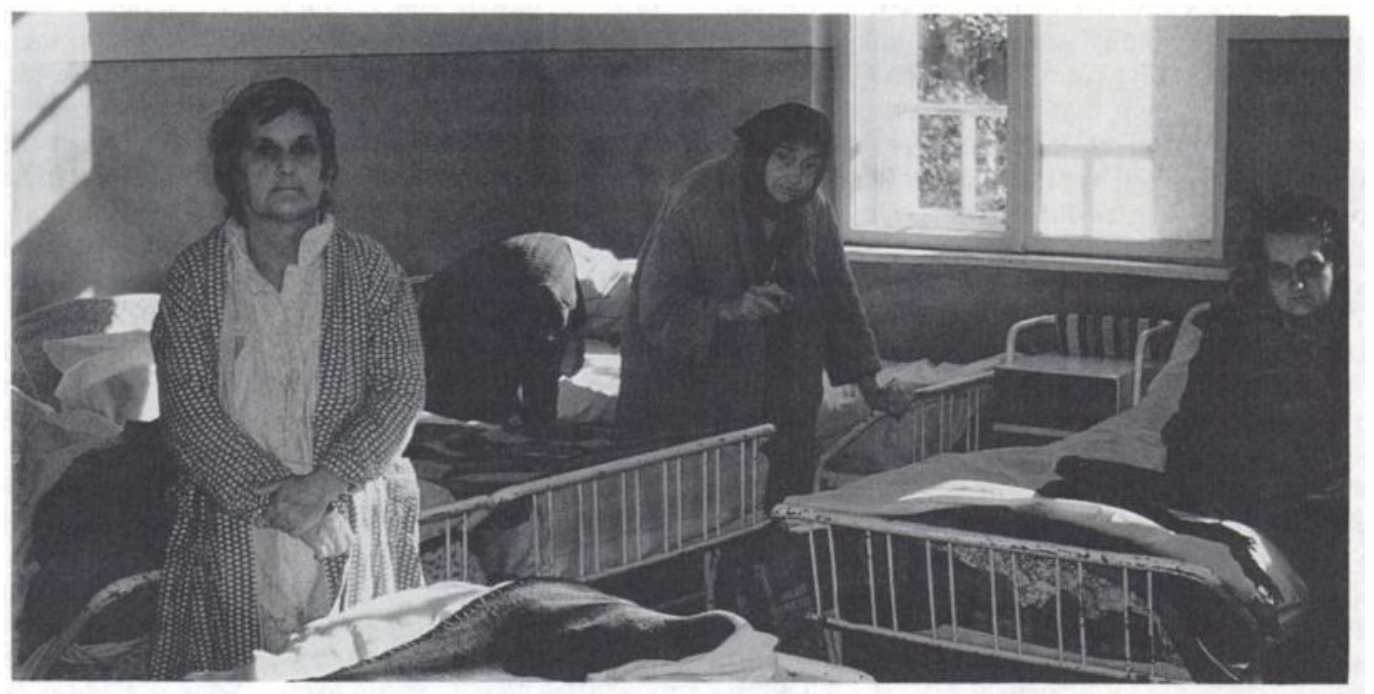

Female 'salon' (ward) in a psychiatric hospital - few staff, no activities, no drugs. 


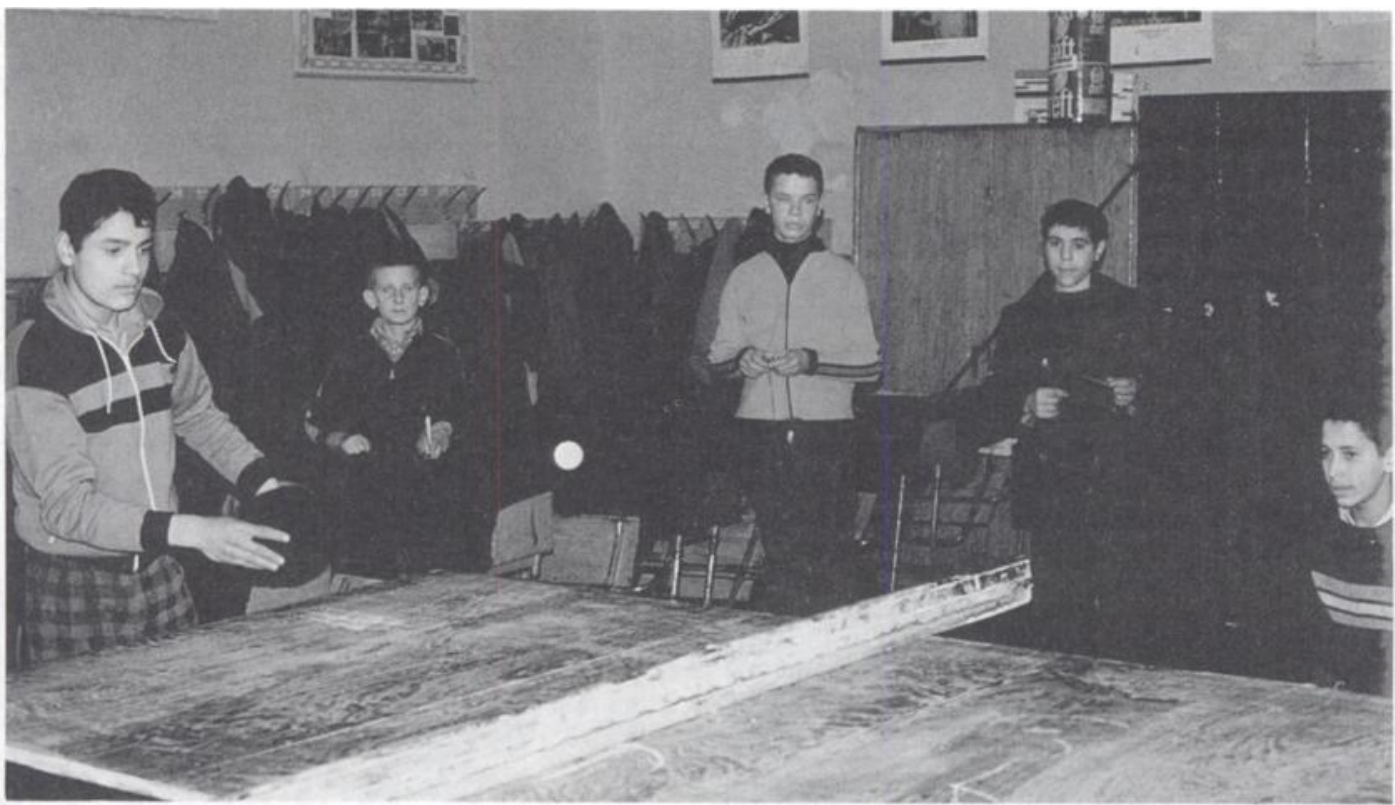

Classroom, wardrobes, recreation room, general storage space in one in a special school.

These are early days, however. Once emergency relief operations have been successfully concluded, serious consideration will have to be given to how future aid can be most effectively targeted. Some uncomfortable facts and issues will have to be borne in mind. Years of repression and material shortages have conditioned people, understandably in my view, to grasp at whatever was available for themselves and their immediate families. Altruism and charity are not concepts that people readily understand. (This was vividly demonstrated in a recent 'Blue Peter' programme.) Although no less a personage than the Prime Minister of Romania is the patron of the society for the mentally handicapped, it is difficult to justify to the local population and particularly to the bureaucracy that the mentally handicapped and the mentally ill are people whose needs are a priority.

It should come as no surprise to find that a signifcant proportion of aid intended, say, for an orphanage, never gets there. The priority for carers is not the orphans in their care but their own families. There is in addition a thriving black market dealing in the buying and selling of imported goods in Romania and neighbouring countries. In providing further aid, therefore, should Western conceptions of basic living standards apply, or should future aid endeavour to raise the standard of the institutions described and the unfortunate individuals therein to that of the rest of the population, with subsequent improvement reflecting the improvements in society generally? Experience elsewhere in the world, notably sub-
Saharan Africa in recent years, suggests that massive outpouring of aid in the form of food and clothing provides very short term benefit indeed. What is needed is sustained efforts at developing a basic infrastructure along with a programme of education aimed at modifying attitudes. Individuals, organisations and governments can all be involved in this process.

At the time of writing, Romania is not eligible for funds from any of the European Grants set up to provide assistance to Eastem bloc countries. It is, of course, possible that they may qualify for eligibility at some point in the future.

Our Department is in the process of establishing links with the Department of Psychology in ClujNapoca University, in conjunction with Bristol MENCAP. For example, teams from Wales will shortly be visiting that University to set up training workshops. We are hoping to have funds released to enable students from Cluj-Napoca to be attached to our Department in Cardiff University for perhaps three months at a time. We have also set up a fund with the aim of purchasing basic equipment, for example, typewriters, copying machines and so on, and in providing books and journals. Bristol MENCAP are hoping to lease a property in Cluj-Napoca to establish a permanent presence there, and it is envisaged that volunteers will rotate through the year providing expertise in areas as diverse as plumbing and physiotherapy. We will gratefully receive any offers of help from readers. At the moment we are particularly looking for cash to buy appropriate equipment and books and journals on psychiatry and psychology. 